\title{
Hubungan Tingkat Pengetahuan dan Sikap dengan Tindakan Masyarakat Terhadap Pencegahan Penyakit Chikungunya dan Vektornya di Nagari Saniang Baka, Kabupaten Solok
}

Taufik Ramadhani ${ }^{1}$, Hasmiwati $^{2}$, Yenita $^{3}$

\section{Abstrak}

Chikungunya adalah penyakit yang disebabkan oleh virus Chikungunya yang ditularkan ke manusia melalui gigitan nyamuk. Di Sumatera Barat terdapat peningkatan kasus Chikungunya yang signifikan yaitu dari 11 kasus pada tahun 2011 menjadi 1607 kasus di tahun 2012. Peningkatan kasus tertinggi terjadi di kabupaten Solok, yaitu sebanyak 1400 kasus, selanjutnya kota Padang 168 kasus, kota Bukittinggi 34 kasus dan kota Pariaman sebanyak 5 kasus. Tujuan penelitian ini adalah menentukan tingkat pengetahuan, sikap dan tindakan masyarakat mengenai pencegahan penyakit Chikungunya dan vektornya.Penelitian dilakukan pada bulan November 2012 - bulan Oktober 2013 di nagari Saning Bakar kabupaten Solok. Jenis penelitian yang digunakan adalah analitik dengan desain cross sectional, dengan jumlah sampel sebanyak 127 orang diambil secara simple random sampling dan dianalisis menggunakan uji chi-square,hasil analisis dikatakan bermaknajika $p<0,05$. Hasil penelitian menunjukkan, sebanyak 106 orang $(83,5 \%)$ memiliki tingkat pengetahuan yang rendah, sebanyak 125 orang $(98,43 \%)$ memiliki sikap yang positif, serta sebanyak 88 orang $(69,3 \%)$ memiliki tindakan yang kurang baik terhadap pencegahan penyakit Chikungunya dan vektornya. Disimpulkan bahwa antara tingkat pengetahuan dengan tindakan masyarakat dalam pencegahan penyakit Chikungunya dan vektornya didapatkan hubungan yang tidak bermakna, tetapi antara sikap dengan tindakan pencegahan penyakit Chikungunya didapatkan cenderung ada hubungan.

Kata kunci: tingkat pengetahuan, sikap, tindakan, chikungunya

\section{Abstract}

Chikungunya is a disease that is caused by Chikungunya virus that is transmitted to human by mosquito bites. There is a significant increase of Chikungunya case from 11 cases in 2011 to 1607 cases in 2012 in West Sumatera. Highest rate of chikungunya disease in Solok regency (1400 cases), Padang (168 cases), Bukittinggi (34 cases) and Pariaman (5 cases). The objective of this study was to determine knowledge, attitude and practice of people about prevention of Chikungunya desease and its vector. The research was carried out on November 2012 to Oktober 2013 in Saning Bakar village, Solok regency. The type of this research was analytic study with cross sectional design with 127 person sample by simple random sampling. The result was analysed by chi-square test, had been meant significant if $p<0,05$. The result showed that, 106 subjects (83,5\%) had low knowledge, an amount of 125 subject $(98,43 \%)$ had positive of attitude and amount of 88 person $(69,3 \%)$ had bad practice about prevention of Chikungunya desease. It was concluded that between knowledge and practice about prevention of Chikungunya disease and its vector there was no significant relation. Between attitude and practiceaboutprevention of Chikungunya disease, there was tendency that can be relation.

Keywords: :knowledge, attitude, practice, chikungunya

Affiliasi penulis: 1. Prodi Profesi Dokter FK Unand (Fakultas Kedokteran Universitas Andalas Padang) 2. Bagian Parasitologi FK Unand 3. Bagian Patologi Anatomi FK Unand.
Korespondensi: Taufik Ramadhani, Email:Taufikr173@gmail.com. Telp:085766141355 


\section{PENDAHULUAN}

Chikungunya adalah penyakit yang disebabkan oleh virus Chikungunya yang ditularkan ke manusia melalui gigitan nyamuk. Nama penyakit berasal dari bahasa Swahili yang berarti "yang berubah bentuk atau bungkuk", mengacu pada postur penderita yang membungkuk akibat nyeri sendi yang hebat. Chikungunya tergolong arthropod-borne disease, yaitu penyakit yang disebarkan oleh arthropoda khususnya nyamuk Aedes aegypti dan Aedes albopictus. Nyamuk ini memiliki kebiasaan menggigit pada siang hari, sehingga kejadian penyakit ini lebih banyak terjadi pada wanita dan anak-anak dengan alasan mereka lebih banyak berada di rumah siang hari. Penyakit ini ditandai dengan demam, myalgia, arthralgia, ruam kulit, leukopenia, limfadenopati dan penderita mengalami kelumpuhan motorik yang tidak permanen. $^{1-3}$

Penderita Chikungunya umumnya sembuh secara spontan dan diikuti dengan imunitas homolog yang berlangsung lama, terjadinya serangan kedua oleh penyakit ini belum diketahui. Infeksi yang tidak jelas sering terjadi, terutama pada anak-anak. Pada saat terjadi wabah, poliartritis dan arthritis lebih sering terjadi pada wanita dewasa dan pada orang-orang yang secara genetis memiliki fenotip HLA (human leucocyte antigen) DR7 Gm a+x+b+. ${ }^{4}$

Chikungunya tersebar di daerah tropis dan subtropis yang berpenduduk padat seperti Afrika, India dan Asia tenggara. Di Afrika, virus ini dilaporkan menyerang di Zimbabwe, Kongo, Kenya dan Uganda. Pertama kali terjadi di Tanzania pada tahun 1952, negara selanjutnya yang terserang adalah Thailand pada tahun 1958; Kamboja, Vietnam, Srilanka dan India pada tahun 1964, 2006 di Pakistan serta tahun 2007 di Kerala, India yang menyerang sekitar 7000 penderita. Di Indonesia, Chikungunya pertama kali dilaporkan pada tahun 1973 yang terjadi di Samarinda, selanjutnya di Kuala Tungkal (Jambi) tahun 1980 dan di Martapura, Ternate serta Yogyakarta tahun 1983.Kejadian Luar Biasa (KLB) demam Chikungunya di Bogor, Bekasi, Purworejo dan Klanten pada tahun 2002. Lokasi penyebaran penyakit ini tidak jauh berbeda dengan demam berdarah Dengue karena vektornya sama yaitu nyamuk Aedes aegypti dan Aedes albopictus. ${ }^{3,5,6}$
Di Sumatera Barat sendiri terdapat peningkatan kasus Chikungunya yang sangat signifikan yaitu dari 11 kasus pada tahun 2011 menjadi 1607 kasus di tahun 2012. Peningkatan kasus tertinggi terjadi di kabupaten Solok yaitu sebanyak 1400 kasus, sisanya kota Padang 168 kasus, kota Bukittinggi 34 kasus dan kota Pariaman sebanyak 5 kasus. Data kasus Chikungunya dinas kesehatan kabupaten Solok tahun 2012, dilihat berdasarkan wilayah kerja Puskesmas sekabupaten Solok yang terdiri atas 18 Puskesmas, kejadian kasus Chikungunya tahun 2012 terjadi di 3 wilayah kerja Puskesmas yaitu wilayah kerja Puskesmas Singkarak, wilayah kerja Puskesmas Selayo dan wilayah kerja Puskesmas Tanjung Bingkung. Jika dilihat berdasarkan tingkat nagari, kejadian kasus Chikungunya terbanyak dan terbaru terjadi di nagari Saniang Baka yang merupakan wilayah kerja Puskesmas Singkarak. Kejadian kasus Chikungunya di Saniang Baka terbanyak terjadi di Jorong Balai Gadang. ${ }^{7-9}$

Peningkatan kasus ini tentunya dipengaruhi oleh perilaku masyarakat dalam pencegahan penyakit Chikungunya. Seperti pengelolaan botol-botol bekas minuman dan benda-benda yang dapat menampung air yang berserakan disekitar rumah, karena dapat menjadi media berkembang biak bagi vektor penyakit Chikungunya. Dari 10 rumah yang diobservasi, pada 7 rumah ditemukan botol-botol bekas minuman dan benda-benda yang dapat menampung air lainnya yang berserakan disekitar rumah. Saat dilakukan wawancara terhadap masing-masing pemilik rumah mengenai pengaruh benda-benda yang dapat menampung air yang berserakan di sekitar rumah terhadap peningkatan kasus Chikungunya, 5 orang menjawab dengan yakin faktor tersebut berpengaruh dan 5 orang lainnya menjawab dengan ragu-ragu bahwa faktor tersebut berpengaruh. Di samping itu sebagian besar masyarakat juga punya kebiasaan membuang sampah di kebun yang dekat dari rumahnya (450 Ha tanah di nagari Saning Bakar digunakan untuk perkebunan). ${ }^{10}$

Terbentuknya perilaku yang kurang baik dalam pengelolaan botol-botol bekas minuman dan bendabenda yang dapat menampung air lainnya yang berserakan di sekitar rumah, tentunya berhubungan dengan tingkat pengetahuan dan sikap masyarakat 
mengenai tindakan pencegahan penyakit Chikungunya. Sesuai dengan yang disampaikan oleh Notoatmodjo di tahun 2007, perubahan prilaku itu mengikuti beberapa tahapan, yakni melalui proses perubahan: pengetahuan (knowledge) kemudian menjadi sikap (attitude) kemudian menjadi praktik (practice) dapat disingkat dengan PSP. ${ }^{11}$

\section{METODE}

Jenis penelitian ini adalah analitik dengan pendekatan cross sectional. Sesuai dengan tujuan dari penelitian ini, yaitu mempelajari hubungan antara variabel independen (tingkat pengetahuan dan sikap masyarakat mengenai pencegahan penyakit Chikungunya) dengan variabel dependen (Tindakan masyarakat mengenai pencegahan penyakit Chikungunya), dimana pengukuran variabel dilakukan sekali dan dalam waktu yang sama. Penelitian dilakukan dari bulan November 2012 sampai Oktober 2013. Lokasi penelitian dilakukan di nagari Saning Bakar, Kecamatan X Koto Singkarak, Kabupaten Solok, tepatnya di Jorong Balai Gadang yang merupakan tempat terbanyak kejadian kasus Chikungunya di Saniang Baka.

Populasi dalam penelitian ini berdasarkan pada jumlah rumah tangga di lokasi penelitian. Dari tiap rumah tangga akan di wawancarai 1 ibu rumah tangga, karena ibu rumah tangga yang memiliki kesempatan yang lebih banyak untuk melakukan PSN seperti menguras bak mandi dan tindakan PSN lainnya. Jumlah sampel sebesar 127 orang diambil secara simple random sampling. Data hasil wawancara yang telah didapatkan dianalisis secara univariat dan bivariat. Analisis univariat untuk mengetahui distribusi frekuensi dari masing-masing variabel, sementara analisis bivariat untuk mengetahui hubungan antara tingkat pengetahuan dengan tindakan, serta hubungan antara sikap dengan tindakan pencegahan penyakit chikungunya dan vektornya. Analisis bivariat menggunakan uji chisquare, perbedaan dinyatakan bermakna jika $p \leq 0,05$.
Hasil

Wawancara telah dilakukan terhadap 127 orang responden.Dari hasil wawancara didapatkan riwayat pendidikan terakhir responden sebagai berikut.

Tabel 1. Distribusi riwayat pendidikan akhir responden

\begin{tabular}{lcc}
\hline Riwayat pendidikan terakhir & $\mathbf{f}$ & $\mathbf{( \% )}$ \\
\hline SD atau sederajat & 29 & 22,8 \\
SMP atau sederajat & 42 & 33,1 \\
SMA atau sederajat & 44 & 34,6 \\
Perguruan tinggi & 12 & 9,4 \\
\hline Jumlah & 127 & 100 \\
\hline
\end{tabular}

Berdasarkan Tabel 1 dapat diketahui bahwa, riwayat pendidikan terakhir yang paling banyak adalah tamat SMA atau sederajat (44 orang atau 34,6\%). Sementara riwayat pendidikan terakhir yang paling sedikit adalah tamat perguruan tinggi yaitu hanya 12 orang $(9,4 \%)$.

Tabel 2. Distribusi frekuensi tingkat pengetahuan responden mengenai pencegahan penyakit Chikungunya dan vektornya

\begin{tabular}{ccc}
\hline Pengetahuan & $\mathbf{f}$ & $\mathbf{( \% )}$ \\
\hline Tinggi & 21 & 16,5 \\
Rendah & 106 & 83,5 \\
\hline Jumlah & 127 & 100 \\
\hline
\end{tabular}

Pada Tabel 2 dapat diketahui bahwa dari 127 responden, berdasarkan tingkat pengetahuan responden mengenai pencegahan penyakit Chikungunya dan vektornya. Sebagian besar (106 orang atau $83,5 \%$ ) memiliki tingkat pengetahuan yang rendah. Responden yang tidak mengetahui jenis nyamuk yang menularkan penyakit Chikungunya sebanyak $97,6 \%$. Tidak mengetahui tentang abatisasi sebanyak $77,2 \%$. Tidak mengetahui tanda-tanda penderita penyakit Chikungunya sebanyak 76,4\%, Tidak mengetahui kapan waktu tersering nyamuk penular penyakit Chikungunya menggigit manusia sebanyak $66,1 \%$. 
Tabel 3. Distribusi frekuensi sikap responden mengenai pencegahan penyakit Chikungunya dan vektornya

\begin{tabular}{ccc}
\hline Sikap & $\mathbf{f}$ & $\mathbf{( \% )}$ \\
\hline Positif & 125 & 98,43 \\
Negatif & 2 & 1,57 \\
\hline Jumlah & 127 & 100 \\
\hline
\end{tabular}

Berdasarkan Tabel 3 dapat diketahui bahwa dari 127 responden, mengenai sikap responden tentang pencegahan penyakit Chikungunya dan vektornya. Sebanyak 125 orang (98,43\%) memiliki sikap yang positif terhadap pencegahan penyakit Chikungunya dan vektornya, diantaranya sebanyak 94 orang $(74,0 \%)$ setuju bahwa bak mandi harus dikuras seminggu sekali. Hanya 2 orang $(1,57 \%)$ yang memiliki sikap yang negatif terhadap pencegahan penyakit Chikungunya dan vektornya, diantaranya hanya sebanyak 5 orang $(3,9 \%)$ tidak setuju kain-kain yang tergantung harus dilipat supaya tidak menjadi sarang nyamuk.

Tabel 4. Distribusi frekuensi tindakan responden mengenai pencegahan penyakit Chikungunya dan vektornya

\begin{tabular}{ccc}
\hline Tindakan & $\mathbf{f}$ & $\mathbf{( \% )}$ \\
\hline Baik & 39 & 30,7 \\
Kurang baik & 88 & 69,3 \\
\hline Jumlah & 127 & 100
\end{tabular}

Berdasarkan Tabel 4 dapat diketahui bahwa lebih dari separuh responden (88 orang atau 69,3\%) memiliki tindakan yang kurang baik terhadap pencegahan penyakit Chikungunya dan vektornya. Hasil observasi di lapangan didapatkan sebanyak $72,4 \%$ terdapat kaleng bekas, ban bekas dan plastik yang dapat menampung air sebagai media berkembang biak nyamuk yang berserakan di sekitar rumah. Hanya 39 orang $(30,7 \%)$ memiliki tindakan yang baik terhadap pencegahan penyakit Chikungunya dan vektornya. Hasil observasi dilapangan didapatkan hanya $33,9 \%$ responden memasang kawat kasa pada ventilasi rumah untuk mencegah nyamuk.
Tabel 5. Hubungan tingkat pengetahuan dengan tindakan pencegahan penyakit Chikungunya dan vektornya.

\begin{tabular}{rcccccc}
\hline & & \multicolumn{3}{c}{ Tindakan } & p \\
& & \multicolumn{2}{c}{ Kurang } & \multicolumn{2}{c}{ Baik } & \\
& & baik & & & \\
& & $\mathbf{f}$ & $\%$ & $\mathbf{f}$ & $\%$ & \\
\hline Pengetahuan & Rendah & 76 & 71,7 & 30 & 28,3 & 0,186 \\
& Tinggi & 12 & 51,7 & 9 & 42,9 & \\
Total & & 88 & 69,3 & 39 & 30,7 & \\
\hline
\end{tabular}

Tabel 5 di atas dapat dilihat bahwa responden dengan pengetahuan rendah lebih banyak memiliki tindakan kurang baik $(71,7 \%)$ dari pada tindakan baik $(28,3 \%)$. Hasil analisis data didapatkan tidak terdapat hubungan bermakna antara tingkat pengetahuan dengan tindakan masyarakat mengenai pencegahan penyakit Chikungunya dan vektornya karena didapatkan nilai $p$ value $0,186(p>0,05)$.

Tabel 6. Hubungan sikap dengan tindakan pencegahan penyakit Chikungunya.

\begin{tabular}{cccccccc}
\hline & \multicolumn{4}{c}{ Tindakan } & \multicolumn{2}{c}{ Total } \\
\cline { 3 - 6 } & & \multicolumn{2}{c}{ Kurang bail } & \multicolumn{2}{c}{ Baik } & \\
\cline { 2 - 7 } & & $\mathbf{f}$ & $\%$ & $\mathbf{f}$ & $\%$ & $\mathbf{f}$ & $\%$ \\
\hline Sikap & neg & 2 & 100 & 0 & 0 & 2 & 100 \\
& pos & 86 & 68,8 & 39 & 31,2 & 125 & 100 \\
\hline Total & & 88 & 69,3 & 39 & 30,7 & 127 & 100
\end{tabular}

Uji chi-square tidak dapat digunakan karena terdapat sel yang bernilai nol. Dari hasil wawancara didapatkan responden yang memiliki sikap negatif $100 \%$ dengan tindakan yang kurang baik, sementara responden yang memiliki sikap positif, hanya $68,8 \%$ dengan tindakan yang kurang baik. Dari perbandingan tersebut dapat dilihat cenderung terdapat hubungan antara sikap dengantindakan responden dalam pencegahan penyakit Chikungunya dan vektornya.

\section{PEMBAHASAN}

Tingkat pengetahuan, Sikap dan Tindakan pencegahan penyakit Chikungunya dan vektornya

Berdasarkan Tabel 2 dinyatakan bahwa dari hasil wawancara terhadap 127 responden di lapangan, berdasarkan tingkat pengetahuan mengenai cara 
pencegahan penyakit Chikungunya dan vektornya. Didapatkan sebanyak 106 orang $(83,5 \%)$ memiliki tingkat pengetahuan yang rendah tentang pencegahan penyakit Chikungunya dan vektornya, hanya 21 orang $(16,5 \%)$ yang memiliki tingkat pengetahuan yang tinggi mengenai pencegahan penyakit Chikungunya dan vektornya. sehingga dapat disimpulkan sebagian besar responden memiliki tingkat pengetahuan yang rendah terhadap pencegahan penyakit Chikungunya dan vektornya.

Rendahnya tingkat pengetahuan masyarakat mengenai pencegahan penyakit Chikungunya dan vektornya diperkirakan dipengaruhi oleh riwayat pendidikan responden. Lebih dari separuh responden (71 orang atau 55,9\%) memiliki riwayat pendidikan terakhir SD dan SMP sederajat, hanya 12 orang $(9,4 \%)$ yang memiliki riwayat pendidikan terakhir perguruan tinggi (PT).

Hasil penelitian ini sesuai dengan penelitian yang dilakukan oleh Perwati pada tahun 2010 di Pasaman Barat, lebih dari separuh responden (sebanyak 68,2\%) yang mempunyai pengetahuan yang rendah tentang penyakit Chikungunya. Penelitian yang dilakukan oleh Nagpal et al di tahun 2012 yang dilakukan di India, juga lebih dari separuh responden (84\%) memiliki pengetahuan yang rendah mengenai pencegahan penyakit Chikungunya. Responden dengan riwayat pendidikan yang rendah akan cendrung lebih sulit mengetahui konsep penularan penyakit Chikungunya, sehingga lebih cenderung terkena penyakit Chikungunya, sesuai dengan yang disampaikan oleh Moro et al, bahwa responden dengan pendidikan rendah lebih cenderung memiliki resiko tinggi terkena penyakit Chikungunya. Perbedaan persentase tingkat pengetahuan responden dari masing-masing hasil penelitian diperkirakan karena berbedanya karakteristik responden dari masing-masing penelitian, seperti perbedaan tingkat kepedulian masing-masing responden terhadap akar permasalahan yang menjadi sumber penyakit Chikungunya disekitar lingkungannya. ${ }^{12-14}$

\section{Sikap masyarakat dalam pencegahan penyakit} Chikungunya dan vektornya

Berdasarkan Tabel 3 dinyatakan bahwa dari hasil wawancara terhadap 127 responden di lapangan. Sebanyak 125 orang responden $(98,43 \%)$ memiliki sikap yang positif terhadap pencegahan penyakit Chikungunya dan vektornya, sementara hanya 2 orang $(1,57 \%)$ yang memiliki sikap yang negatif terhadap pencegahan penyakit Chikungunya dan vektornya. Sehingga dapat dilihat bahwa, hampir semua responden memiliki sikap yang positif terhadap pencegahan penyakit Chikungunya dan vektornya.

Hasil penelitian ini sesuai dengan penelitian Sari pada tahun 2007, lebih dari separuh responden $(53,33 \%)$ memiliki sikap yang positif. Pada penelitian Rosvara dan Roza di tahun 2013 juga hampir semua (90\%) memiliki sikap yang positif dalam pencegahan penyakit Chikungunya, namun berbeda dengan hasil penelitian Laxmi pada tahun 2011, dimana 66\% responden memiliki sikap yang negatif. Perbedaan hasil penelitian mengenai sikap responden, juga diperkirakan karena perbedaan karakteristik dari masing-masing responden. ${ }^{15-17}$

Dalam hasil penelitian ini, didapatkan makin positif atau negatifnya sikap responden tidak sejalan dengan makin tinggi atau rendahnya tingkat pengetahuan responden mengenai pencegahan penyakit Chikungunya dan vektornya. Karena walaupun sebagian besar responden $(83,5 \%)$ memiliki tingkat pengetahuan yang rendah mengenai pencegahan penyakit Chikungunya dan vektornya, namun sebanyak 125 orang (98,43\%) memiliki sikap yang positif terhadap pencegahan penyakit Chikungunya dan vektornya. Hal ini diperkirakan karena sikap tidak hanya dipengaruhi oleh tingkat pengetahuan saja, namun juga oleh banyak faktor lainnya. Sesuai dengan Notoatmodjo (2003), ${ }^{18}$ Sikap dipengaruhi oleh beberapa hal yaitu pengalaman pribadi, interaksi sosial, pengaruh orang lain yang dianggap penting, kebudayaan, informasi serta emosional. Pada responden dari penelitian yang telah dilakukan, diperkirakan terdapat sebagian responden 
dipengaruhi oleh faktor emosional, karena ada responden yang dengan terus terang mengatakan malas untuk melakukan tindakan pencegahan tersebut walaupun sudah diberi tahu akibatnya kalau tindakan tersebut tidak dilakukan.

Hasil wawancara didapatkan sebanyak $66,1 \%$ responden menyatakan setuju bahwa obat nyamuk hanya digunakan pada malam hari. Ini merupakan sikap yang negatif karena nyamuk Aedes aegypti biasanya menghisap darah pada pagi hari pukul 08.00-10.00 dan sore hari pukul 15.00-17.00.

\section{Tindakan masyarakat dalam pencegahan penyakit Chikungunya dan vektornya}

Berdasarkan Tabel 4 dinyatakan bahwa dari hasil observasi dilapangan terhadap 127 responden, sebanyak 88 orang $(69,3 \%)$ memiliki tindakan yang kurang baik terhadap pencegahan penyakit Chikungunya dan vektornya, sementara hanya 39 orang $(30,7 \%)$ memiliki tindakan yang baik terhadap pencegahan penyakit Chikungunya dan vektornya. Sehingga dapat dilihat bahwa, lebih dari separuh responden memiliki tindakan yang kurang baik terhadap pencegahan penyakit Chikungunya dan vektornya.

Hal ini diperkirakan dipengaruhi oleh riwayat pendidikan responden, dimana lebih dari separuh responden (71 orang atau 55,9\%) memiliki riwayat pendidikan terakhir SD dan SMP sederajat serta hanya 12 orang $(9,4 \%)$ yang memiliki riwayat pendidikan terakhir perguruan tinggi (PT). Karena tingkat pendidikan akan mempengaruhi tingkat pengetahuan responden. Sesuai dengan yang disampaikan oleh Junaida di tahun 2003, bahwa, pendidikan yang relatif rendah akan melatarbelakangi sulitnya responden dalam mengetahui konsep pencegahan penyakit. Rendahnya pengetahuan responden mengenai pencegahan penyakit, tentunya berpengaruh terhadap tindakan responden dalam pencegahan penyakit tersebut. Sesuai dengan yang dinyatakan oleh Notoadmodjo pada tahun 2007, seseorang akan lebih termotivasi melakukan suatu tindakan ketika dia mengetahui apa manfaat tindakan tersebut bagi diri atau keluarganya, serta bahaya jika tindakan tersebut tidak dilakukan. ${ }^{11,19}$
Hasil penelitian ini sesuai dengan penelitian yang dilakukan oleh Megawati pada tahun 2008 di Padang. Dari hasil penelitian tersebut didapatkan lebih dari separuh responden(80\%) memiliki tindakan yang kurang baik dalam pencegahan penyakit Chikungunya. Hasil observasi dilapangan didapatkan $96,1 \%$ responden tidak menaburkan bubuk abate di tempat penampungan air, masih banyak responden yang khawatir penggunaan bubuk abate pada tempat penampungan air dapat mengakibatkan air tersebut tidak aman digunakan untuk mandi maupun untuk menggosok gigi. ${ }^{20}$ Serta sebanyak $72,4 \%$ responden, masih terdapat kaleng bekas, ban bekas dan plastik yang dapat menampung air di sekitar rumahnya, hal ini diperkirakan karena kegiatan gotong royong berkala masih belum berjalan dengan baik. Hasil penelitian ini sama dengan penelitian Muldie pada tahun 2003 di desa Langosari kabupaten Bandung yang mengemukakan bahwa juga masih terdapat kaleng-kaleng bekas yang berserakan, dimana kalengkaleng bekas dapat menampung air dan sangat sesuai sebagai tempat perindukan nyamuk. Hasil observasi dilapangan hanya $68,5 \%$ bak mandi yang bersih dari jentik nyamuk ini belum mencapai indikator yang diharapkan yaitu $>95 \%$ hal ini diperkirakan karena belum optimalnya pelaksanaan PJB dan larvasidasi oleh petugas dan kader jumantik. Hasil penelitian ini sama dengan yang dilakukan oleh Dianis pada tahun 2012 di Bengkalis, yaitu hasil penelitian tersebut angka bebas jentik juga belum mencapai indikator yang diharapkan yaitu $85,83 \%(<96 \%) .{ }^{21,22}$

\section{Hubungan tingkat pengetahuan dan sikap dengan tindakan pencegahan penyakit Chikungunya dan vektornya}

Hasil analisis data didapatkan tidak terdapat hubungan bermakna antara tingkat pengetahuan dengan tindakan masyarakat mengenai pencegahan penyakit Chikungunya dan vektornya $(p>0,05)$. Hal ini disebabkan karena selain tingkat pengetahuan, tindakan pencegahan penyakit Chikungunya juga dipengaruhi oleh faktor-faktor lainnya. Diantaranya faktor emosional seseorang, seperti kemampuan seseorang untuk mengendalikan dirinya dari hal-hal yang berdampak kurang baik bagi dirinya, sesuai 
dengan teori yang dikembangkan oleh Fesbein dan Azjen dalam Notoatmodjo pada tahun 2010 yang menekankan niat sebagai alasan atau faktor penentu perilaku. Selanjutnya niat ini ditentukan oleh Sikap, Norma Subjektif dan pengendalian diri. ${ }^{23}$

Hasil penelitian ini sesuai dengan hasil penelitian yang dilakukan oleh Aztari pada tahun 2007 di Kelurahan Aur Kuning Kecamatan Aur Birugo Tigo Baleh, Bukittinggi. Dari hasil penelitian tersebut, antara tingkat pengetahuan dengan tindakan juga tidak terdapat hubungan yang bermakna. Hasil penelitian Rosvara dan Roza pada tahun 2013 yang mana antara tingkat pengetahuan dan tindakan juga tidak terdapat hubungan yang bermakna. ${ }^{16,24}$

Analisis data mengenai hubungan sikap dan tindakan pencegahan penyakit Chikungunya dengan uji chi-square tidak dapat digunakan karena terdapat sel yang bernilai nol. Dari hasil wawancara didapatkan responden yang memiliki sikap negatif $100 \%$ dengan tindakan yang kurang baik, sementara responden yang memiliki sikap positif, hanya $68,8 \%$ dengan tindakan yang kurang baik. Dari perbandingan tersebut dapat dilihat cenderung terdapat hubungan antara sikap dengan tindakan responden dalam pencegahan penyakit Chikungunya. Penelitian lainnya yang pernah dilakukan oleh Perwati pada tahun 2010 terhadap 107 responden di Nagari Aur kuning, Kecamatan Pasaman, Kabupaten Pasaman Barat, didapatkan tidak terdapat hubungan yang bermakna antara sikap dengan tindakan pencegahan penyakit Chikungunya. ${ }^{12}$

Tidak terdapatnya hubungan yang bermakna antara sikap dengan tindakan, diperkirakan karena adanya faktor-faktor lain yang mempengaruhi tindakan seseorang dalam pencegahan penyakit Chikungunya. Seperti faktor kesibukkan, misalnya dalam tindakan menguras bak mandi 2 kali dalam seminggu, walaupun seseorang setuju bahwa bak mandi perlu dikuras 2 kali seminggu untuk mencegah perkembang biakan jentik nyamuk, namun karena faktor kesibukkan menyebabkan orang tersebut tidak sempat untuk menguras bak mandi 2 kali dalam seminggu. Sesuai dengan yang disampaikan oleh Notoatmodjo pada tahun 2007, ${ }^{11}$ suatu sikap belum otomatis terwujud dalam suatu tindakan. Untuk mewujudkan sikap menjadi suatu tindakan nyata, diperlukan faktor pendukung atau suatu kondisi yang memungkinkan. Sesuai dengan teori yang dikemukakan oleh Lawrence Green bahwa perilaku itu terbentuk dari 3 faktor yaitu: faktor Predisposisi (predisposing factors), faktor Pemungkin (enabling factors) dan faktor pendorong (reinforcing factors). Faktor kesibukkan yang mengakibatkan seseorang tidak sempat menguras bak mandi, dapat dikategorikan pada tidak adanya faktor pemungkin (enabling factors) yang mendukung seseorang untuk melakukan tindakan tersebut.

\section{SIMPULAN}

Tidak terdapat hubungan yang bermakna antara tingkat pengetahuan dengan tindakan pencegahan penyakit Chikungunyadi Nagari Saniang Baka Kabupaten Solok.

Terdapat kecendrungan hubungan antara sikap dengan tindakan pencegahan penyakit Chikungunyadi nagari Saniang Baka Kabupaten Solok.

\section{DAFTAR PUSTAKA}

1. Suharto. Chikungunya pada orang dewasa. Dalam: Penyakit infeksi di Indonesia solusi kini dan mendatang. Surabaya: Airlangga University Press; 2007.hIm.104-9.

2. Djakaria S, Sungkar S. Vektor penyakit virus, ricketsia, spiroketa dan bakteri. Dalam: Parasitologi kedokteran. Edisi ke-4. Jakarta. FKUI; 2008.hlm. 265.

3. Widoyono. Chikungunya. Dalam: Penyakit Tropis, epidemiologi, penularan, pencegahan dan pemberantasannya. Edisi ke-2. Jakarta: Erlangga; 2011.hlm.81-6.

4. Chin J. Demam Chikungunya. Dalam: Manual pemberantasan penyakit menular. Edisi ke-17. Jakarta: CV.Infomedika; 2006.hlm.42.

5. Smith DW, Hall RA, Johansen CA, Brow AK and Mackerzie JS. Viral infection. Dalam: Manson tropical desease. Edisi ke-22. Elsavier Saunders; 2009.hlm.726-8.

6. Peter CJ. Infections caused by arthropod and rodent-borne viruses. Dalam: Fauci AS, Kaspar DL, editor (penyunting). Harrison's infectious 
desease. China: Mc Graw-Hill Companies; 2010. hlm.977.

7. Dinas Kesehatan Propinsi Sumatra Barat. Data statistik kasus chikungunya di Sumatra Barat 2011 dan 2012. Padang: Dinas Kesehatan Propinsi Sumatra Barat; 2012.

8. Dinas Kesehatan Kabupaten Solok. Data statistik kasus chikungunya di Kabupaten Solok. Arosuka: Dinas Kesehatan Kabupaten Solok; 2012.

9. Data laporan penderita demam Chikungunya di Nagari Saniang Baka; 2012.

10. Rekapitulasi hasil pendataan keluarga tingkat desa/kelurahan nagari Saniang Baka; 2010.

11. Notoatmodjo S. Kesehatan lingkungan. Dalam: Kesehatan masyarakat ilmu dan seni. Jakarta: Rineka Cipta; 2007.hlm.191- 2.

12. Perwati AD. Faktor-faktor yang berhubungan dengan tindakan masyarakat dalam pencegahan penyakit chikungunya di Nagari Aur Kuning Kecamatan Pasaman Kabupaten Pasaman Barat tahun 2010. Padang (skripsi). Padang: Fakultas Kesehatan Masyarakat Universitas Andalas; 2010.

13. Nagpal BN, Saxena R, Srivastava A, Singh N, Ghosh SK, Sharma SK, et al. Retrospective study of chikungunya outbreak in urban areas of India. Indian Journal of Medical Research. National Institute of Malaria Research (ICMR). Dwarka, New Delhi, India; 2012;135(3):351-8.

14. Moro ML, Gagliotti C, Silvi G, Angelini R, Sambri $\mathrm{V}$, et al. Knowledge, attitudes and practices survey after an outbreak of chikungunya infections. Journal of International Health. 2010;2(3):223-7.

15. Sari MP. Faktor-faktor yang berhubungan dengan tindakan ibu terhadap pencegahan DBD di Kelurahan Jati Baru Padang (skripsi). Padang: Fakultas Kedokteran Universitas Andalas; 2007.

16. Rosvara, Roza F. Pengetahuan, sikap dan perilaku masyarakat kelurahan pasir kuda Kota Bogor terhadap vektor penyakit Chikungunya. IPB repository. Bogor Agricultural University; 2013.
17. Laxmi CB, Ganesh K. Assessment of the knowledge and attitude about chikungunya among the residents of puducherry: A cross-sectional study. Journal of research in medical education and ethics.New Delhi India; 2011;1(3):162-6.

18. Notoatmodjo S. Pendidikan dan perilaku kesehatan. Jakarta: PT Rineka Cipta; 2010.

19. Junaida. Hubungan tingkat pengetahuan dan sikap ibu rumah tangga dengan upaya pemberantasan penyakit DBD di Kelurahan Bangkinang, Kabupaten Kampar tahun 2003 (skripsi). Padang: Fakultas Kesehatan Masyarakat Universitas Andalas; 2003.

20. Megawati W. Faktor-faktor yang berhubungan dengan upaya pencegahan terhadap penyakit Chikungunya di kelurahan Jati, kecamatan Padang Timur tahun 2008. Padang (skripsi). Padang: Fakultas Kesehatan Masyarakat Universitas Andalas; 2008.

21. Muldie. Epidemiologi penyakit chikungunya pada KLB di desa Langosari, Kabupaten Bandung dari bulan April-Juni 2003. Dalam: Perwati AD. Faktorfaktor yang berhubungan dengan tindakan masyarakat dalam pencegahan penyakit Chikungunya di Nagari Aur Kuning Kecamatan Pasaman Kabupaten Pasaman Barat tahun 2010 (skripsi). Padang: Fakultas Kesehatan Masyarakat Universitas Andalas; 2003.

22. Dianis R. Evaluasi pelaksanaan program penanggulangan dan pemberantasan DBD di unit pelaksana teknis Dinas Kesehatan, Puskesmas Kecamatan Mandau Kabupaten Bengkalis tahun 2011 (skripsi). Padang: Fakultas Kesehatan Masyarakat Universitas Andalas; 2012.

23. Notoatmodjo S. Teori-teori perilaku. Dalam: IImu perilaku kesehatan. Jakarta: PT Rineka Cipta; 2010.hlm.74-6.

24. Aztari F, Tingkat pengetahuan, sikap dan tindakan masyarakat mengenai penyakit DBD di kelurahan Aur Kuning Bukit Tinggi (skripsi). Padang: Fakultas Kedokteran Universitas Andalas; 2007. 